JOURNAL of

TOXICOLOGY and

ENVIRONMENTAL

HEALTH
Journal of Toxicology and Environmental Health, Part A

\title{
Fruit extract of the medicinal plant Crataegus oxyacantha exerts genotoxic and mutagenic effects in cultured cells
}

Ana Paula Oliveira de Quadros, Dania Elisa Christofoletti Mazzeo, Maria Aparecida Marin-Morales, Fábio Ferreira Perazzo, Paulo Cesar Pires Rosa \& Edson Luis Maistro

To cite this article: Ana Paula Oliveira de Quadros, Dania Elisa Christofoletti Mazzeo, Maria Aparecida Marin-Morales, Fábio Ferreira Perazzo, Paulo Cesar Pires Rosa \& Edson Luis Maistro (2017) Fruit extract of the medicinal plant Crataegus oxyacantha exerts genotoxic and mutagenic effects in cultured cells, Journal of Toxicology and Environmental Health, Part A, 80:3, 161-170, DOI: $10.1080 / 15287394.2016 .1272517$

To link to this article: https://doi.org/10.1080/15287394.2016.1272517

Published online: 17 Feb 2017.

Submit your article to this journal $\longleftarrow$

Џll Article views: 154

View Crossmark data $\subset$

Citing articles: 4 View citing articles $\sqsubset$ 


\title{
Fruit extract of the medicinal plant Crataegus oxyacantha exerts genotoxic and mutagenic effects in cultured cells
}

\author{
Ana Paula Oliveira de Quadros ${ }^{\mathrm{a}}$, Dania Elisa Christofoletti Mazzeo ${ }^{\mathrm{b}}$, Maria Aparecida Marin-Morales ${ }^{\mathrm{b}}$, \\ Fábio Ferreira Perazzoc, Paulo Cesar Pires Rosa ${ }^{d}$, and Edson Luis Maistro ${ }^{a, e}$
}

\begin{abstract}
aUniversidade Estadual Paulista - UNESP - Instituto de Biociências, Programa de Pós-graduação em Biologia Geral e Aplicada, Botucatu, SP, Brazil; bUniversidade Estadual Paulista - UNESP - Instituto de Biociências, Departamento de Biologia, Rio Claro, SP, Brazil; 'Universidade Federal de São Paulo - UNIFESP - Instituto de Ciências Ambientais, Químicas e Farmacêuticas, Departamento de Ciências Exatas e da Terra, Diadema, SP, Brazil; dUniversidade Estadual de Campinas - UNICAMP - Faculdade de Ciências Médicas, Campinas, SP, Brazil; eUniversidade Estadual Paulista - UNESP - Faculdade de Filosofia e Ciências, Departamento de Fonoaudiologia, Marilia, SP, Brazil
\end{abstract}

\begin{abstract}
Crataegus oxyacantha, a plant of the Rosaceae family also known "English hawthorn, haw, maybush, or whitethorn," has long been used for medicinal purposes such as digestive disorders, hyperlipidemia, dyspnea, inducing diuresis, and preventing kidney stones. However, the predominant use of this plant has been to treat cardiovascular disorders. Due to a lack of studies on the genotoxicity of $C$. oxyacantha, this investigation was undertaken to determine whether its fruit extract exerts cytotoxic, genotoxic, or clastogenic/aneugenic effects in leukocytes and HepG2 (liver hepatocellular carcinoma) cultured human cells, or mutagenic effects in TA100 and TA98 strains of Salmonella typhimurium bacterium. Genotoxicity analysis showed that the extract produced no marked genotoxic effects at concentrations of 2.5 or $5 \mu \mathrm{g} / \mathrm{ml}$ in either cell type; however, at concentrations of $10 \mu \mathrm{g} / \mathrm{ml}$ or higher significant DNA damage was detected. The micronucleus test also demonstrated that concentrations of $10 \mu \mathrm{g} / \mathrm{ml}$ or higher produced clastogenic/aneugenic responses. In the Ames test, the extract induced mutagenic effects in TA98 strain of $S$. typhimurium with metabolic activation at all tested concentrations (2.5 to $500 \mu \mathrm{g} / \mathrm{ml}$ ). Data indicate that, under certain experimental conditions, the fruit extract of $C$. oxyacantha exerts genotoxic and clastogenic/aneugenic effects in cultured human cells, and with metabolism mutagenicity occurs in bacteria cells.
\end{abstract}

\section{ARTICLE HISTORY}

Received 8 November 2016

Accepted 12 December 2016

\section{Introduction}

Crataegus oxyacantha L., a plant of the Rosaceae family that reaches a length of 25 to $30 \mathrm{~m}$, was originally found in Europe, North America, and West Asia, but due to medicinal potential, this plant has since been cultivated in other locations, such as South America. In springtime, C. oxyacantha $\mathrm{L}$. forms large white or pink inflorescence with a distinct aroma; while in the fall, these floral clusters become small shiny red fruits (Weihmayr \& Ernst, 1996). Extracts of this shrub's leaves and flowers and more recently its fruit have been used for several health conditions, especially heart problems (Rigelsky \& Sweet, 2002; Zhang et al., 2001; Nascimento, 2009; Belščakcvitanović et al., 2014; Alp et al., 2015).
This fruit has a long history of use as a diuretic, to treat dyspnea and renal calculus as well as sedative and anxiolytic effects (Rigelsky \& Sweet, 2002). However, most pharmacological studies on this species focused on cardiotonic properties of a mixture of its aerial parts. The protective effect of C. oxyacantha against adverse cardiovascular activity is attributed to flavonoid constituents, particularly oligomeric protoanthocyanidins (OP), which exert significant antioxidant activity (Wang et al., 2013; Chang et al., 2005; Jayalakshmi \& Niranjali-Devaraj, 2004).

The oligomeric protoanthocyanidins $(\mathrm{OP})$ are largely concentrated in the leaves, fruits, flowers, and fruits. Oligomeric protoanthocyanidins are responsible for pigmentation of the fruits. Jayalakshmi and Niranjali-Devaraj (2004)

CONTACT Edson Luis Maistro edson.maistro@marilia.unesp.br @ Departamento de Fonoaudiologia, Faculdade de Filosofia e Ciências, Universidade Estadual Paulista (UNESP), Av. Hygino Muzzi Filho, 737, Caixa Postal 18, Campus Universitário, CEP 17525-900 Marilia, SP, Brazil. 
demonstrated that the extract of this plant reduced oxidative stress in the myocardium after reperfusion and appeared to inhibit apoptosis, resulting in a cardioprotective effect. The standard dose of Crataegus aerial parts extract is 300 to $600 \mathrm{mg}$ three times daily of an extract standardized to contain 2 to $3 \%$ flavonoids or 18 to $20 \%$ procyanidins (Ammon \& Händel, 1981).

Studies on fruit extracts of other Crataegus species (Crataegus microphylla) showed protection of cultured human lymphocytes against the genotoxic effects induced by radiation (Hosseinimehr et al., 2007; 2009; 2011). The Crataegus genus is considered one of the oldest pharmacological sources and widely used in folk medicine (Bahorun et al., 2003).

At present, few studies examined the genetic toxicity of C. oxyacantha extract. Tabach et al. (2009) developed a preclinical toxicological assessment of a phytotherapeutic product-CPV, which consist of dry aerial parts of C. oxyacantha (26.7\%), Passiflora incarnata (33.3\%), and Valeriana officinalis (40\%). The parameters assessed included weight, behavior, estrous cycle, teratogenicity in dogs, rats, or mice, and mutagenicity in bacteria (Ames test). Tabach et al. (2009) reported only negative results, indicating that the CPV mixture was apparently devoid of risk for humans.

Considering the widespread popular use of extract from aerial parts of C. oxyacantha, and lack of studies specifically assessing the genetic toxic potential of fruit extract, this investigation was conducted to determine the cytotoxic, genotoxic, and clastogenic/aneugenic potential in vitro, using human leukocytes and HepG2 cells, as well as mutagenic potential in bacteria cells. Among the available safety tests, the micronucleus (MN) test, comet assay, and Ames test are recommended by international regulatory agencies for toxicological evaluation of natural products (Choy, 2001; Claxton et al., 2010; OECD 489, 2014; Franco et al., 2015; Trindade et al., 2016). Thus, these tests were utilized to determine the safety of $C$. oxyacantha.

\section{Materials and methods}

\section{Botanical material}

C. oxyacantha fruit was collected in Turkey and purchased from certified distributor in Brazil. A sample voucher (LFF00297) was deposited in the Phytochemical Laboratory of José do Rosário Vellano University (Alfenas, MG). Dried and powdered C. oxyacantha fruit, in a ratio of herbal drug to drug preparation of $4-7: 1$, was extracted at room temperature with methanol $70 \% \mathrm{v} / \mathrm{v}$. The macerated fruit was filtered and concentrated under reduced pressure in a rotary evaporator, resulting in crude methanolic extract $(\mathrm{MeOH})$.

\section{Chemicals}

C. oxyacantha extract was diluted in Dulbecco's modified Eagle's medium (DMEM) (Gibco) to be used with HepG2 cells and RPMI-1640 medium (Gibco) to be employed with human lymphocytes. Methyl methane sulfonate (MMS) (Aldrich, CAS number 66-27-3) and benzo(a)pyrene (SigmaAldrich) were utilized as the positive control due to known potential for DNA damage, recognizable in the comet and $\mathrm{MN}$ assays. The other main chemicals were obtained from the following suppliers: trypsin (Sigma-Aldrich), phytohemagglutinin (Sigma-Aldrich), cytocalasin-B (SigmaAldrich), normal melting point (NMP) agarose (Invitrogen), low-melting point (LMP) agarose (Invitrogen), fetal calf serum(FCS) (Gibco), ethylenediaminetetraacetic acid (EDTA) (Merck), Triton X-100 (J.T.Baker), trypan blue (SigmaAldrich), thiazolyl blue tetrazolium bromide ethidium bromide (Sigma), dimethyl sulfoxide (DMSO) (Sigma-Aldrich), Giemsa (Synth), and Histopaque-1077 (Sigma-Aldrich).

\section{Phytochemical analysis of extract}

The $70 \%$ methanolic extract was analyzed using liquid chromatography attached to a mass detector. The chromatographic conditions were as follows: C18 column $(100 \times 2.1 \mathrm{~mm}, 1.7 \mathrm{mcm}$, temperature $30{ }^{\circ} \mathrm{C}$, injection volume $2 \mu \mathrm{l}$, using gradient mode for the mobile phase with mixture I (water: THF: formic acid 890:90:20) and mixture II (methanol:acetonitrile:formic acid 400:400:200) over a $0.2-\mathrm{ml} / \mathrm{min}$ flow. A triple quadrupole detector operating with an electrospray ionization source in the negative mode (ESI -), with desolvation and source temperatures of $300{ }^{\circ} \mathrm{C}$ and $120^{\circ}$ $\mathrm{C}$, respectively, over a $\mathrm{m} / \mathrm{z} 100$ to $\mathrm{m} / \mathrm{z} 1000$ range. 
The solutions were directly infused into the mass spectrometer electrospray ionization source (ESI). The chromatographic separation was performed using a $2.1 \times 100 \mathrm{~mm} \mathrm{C18}$ column packed with $1.7 \mu \mathrm{m}$ particles (Zorbax XDB C18, Agilent) at $30^{\circ} \mathrm{C}$. Mobile phase A consisted of water:tetrahydrofuran:formic acid 0.1\%, 890/90/20 v/v/v, while mobile phase $\mathrm{B}$ consisted of methanol:acetonitrile:formic acid 0.1\%, 400/400/200 v/v/v. The following gradient was used as follows: (0-20 min) $50 \% \mathrm{~B},(20-40 \mathrm{~min}) 100 \% \mathrm{~B}$, and $(40-45 \mathrm{~min})$ $100 \% \mathrm{~A}$. The flow rate was $0.2 \mathrm{ml} / \mathrm{min}$ at room temperature, and the injection volume was $2 \mu$ l.

Equipment: A Waters Acquity UPLC was used. A Waters triple-triple TDQMS/MS mass spectrometer with an electrospray ionization source (ESI) was utilized as a detector. Argonium was employed as a collision gas in the sequential mass analysis. Analyst software (Masslynx) was used for equipment control and data, acquisition and analysis. The analyses were monitored in the full-scan mode, and the mass lines intended for analysis were selected for collisioninduced dissociation.

\section{Cultured human cells}

Peripheral blood mononuclear cells (PBMC) used in this study were obtained by venipuncture from two healthy volunteers (a man and a woman under 25 years of age), according to OECD guidelines (OECD $487,2014)$. The peripheral blood leukocyte (PBL) donors provided written informed consent at the time of donation, as determined by the Ethics Committee. HepG2 cells (human hepatoma cell line) were obtained from the Cell Bank of Rio de Janeiro, Brazil). The PBMC were maintained in cell culture flasks containing RPMI medium, whereas the HepG2 cells were grown in DMEM medium, supplemented with both antibiotics and 10\% FCS. Cultures were incubated at $37^{\circ} \mathrm{C}, 5 \% \mathrm{CO}_{2}$, and $95 \%$ relative humidity, with complete asepsis. This study was approved by the Human Ethics Committee of the Universidade Estadual Paulista (Marília, SP) on December 4, 2013 (protocol 0839/2013).

\section{Determination of cell viability and cytotoxicity}

Cell viability was tested with trypan blue staining, which indicates cell membrane integrity. A total of 2 $\mathrm{x} 10^{5}$ cells were placed in each well of a 24 -well plate. The concentrations tested were $2.5,5,10,25,50,100$, 250, 500, 1000, 1250, 2500, and $5000 \mathrm{ug} / \mathrm{ml}$. The culture plates were maintained in an incubator at $37^{\circ}$ $\mathrm{C}, 5 \% \mathrm{CO}_{2}$. The cellular viability test was performed for both cell types according to Strober (2001) method. The culture medium itself was used as a negative control, and Triton X-100 diluted in medium without fetal bovine serum (FBS) culture was used as positive control. Each concentration was tested twice, and each test was performed in triplicate. After 24-hr incubation in the presence of the test substance, cells were harvested and analyzed under an optical microscope, using a Neubauer chamber as base. Non-viable cells were stained blue, and 100 cells per well were counted.

To assess cytotoxicity, a MTT test (3- [4,5dimethylthiazol-2-yl] -2,5-diphenyltetrazolium) was conducted, with the HepG2 cells Mosmann (1983) with some modifications. The test estimates percent cells capable of transforming MTT into formazan, that is, percent metabolically viable cells. This transformation is indicated by a shift to purple coloration in the solution, which is due to mitochondrial metabolism. The metabolism involves a reduction that utilizes $\mathrm{NADH}$ and similar molecules for electron transfer, which leads to the formation of a product which precipitates and accumulates at the bottom of each well. For precipitate dissolution, DMSO was added to the medium, and the plate was read by custom software applied to a spectrophotometer (Riss, 2013).

To perform the MTT assay, $1 \times 10^{4}$ cells were added to each 96-well plate, which were then filled with culture medium until $2 \mathrm{ml}$ was reached. After 24-hr incubation period, 1.4-ml medium was removed. Twenty $\mu \mathrm{l}$ of each test extract concentration was prepared, and volume was made up to 2 $\mathrm{ml}$. Controls were the same as those employed in the trypan blue staining test. After another 24-hr incubation period, $1.4-\mathrm{ml}$ medium was removed and $200 \mu \mathrm{l}$ MTT was added to each well. The plate was incubated again for a further $4 \mathrm{hr}$, MTT was removed, and then, $200 \mu \mathrm{l}$ DMSO was added. After $5 \mathrm{~min}$, the plate was read with a spectrophotometer, at $540 \mathrm{~nm}$ filter.

\section{Comet assay}

The alkaline comet assay was performed according to Tice et al. (2000). An aliquot of $2 \times 10^{5}$ cells was 
placed into 24 -well plates in 2-ml respective culture medium per well at $37^{\circ} \mathrm{C}$ and incubated for 4 hr with the extract, at concentrations of $2.5,5,10$, 50 , and $100 \mathrm{ug} / \mathrm{ml}$; these concentrations were selected on the basis of cell viability and cytotoxicity tests. The positive control was $75 \mu \mathrm{M}$ MMS, and the negative control was culture medium. Analysis was performed immediately at 400x magnification under fluorescence microscopy with a $515-560 \mathrm{~nm}$ excitation filter and a $590 \mathrm{~nm}$ barrier filter. All experiments were performed three times and in duplicate.

To determine the extent and distribution of DNA damage, single cell gel electrophoresis (SCGE) assay was conducted by examining at least 100 randomly selected and non-overlapping cells ( 50 cells per coded slide) per culture well was conducted in a blind fashion. These cells were scored visually (Azqueta et al., 2011), according to tail size into the following four classes: class 0 no tail; class 1- tail shorter than the diameter of the head (nucleus); class 2- tail length 1- to twofold greater than the diameter of the head; and class 3- tail length more than twofold the diameter of the head. Headless comets (class 4) with almost all the DNA in the tail or those with a wide tail were excluded from the evaluation given the likelihood that they were dead cells (Fairbairn et al., 1995; Hartmann \& Speit, 1997). The score for each treatment was obtained by multiplying the number of nucleoids observed in each damage class by the value of the class $(0,1,2$, or 3$)$.

\section{Cytokinesis-block micronucleus (CBMN) test}

The CBMN test was performed according to the Fenech (2000) protocol, having been recently revised and standardized by the OECD (OECD 487, 2014). Cells were cultured and treated with the same five concentrations evaluated in the comet assay. The positive control was $150 \mu \mathrm{M}$ MMS for PBL and $2 \mu \mathrm{M}$ benzo[a]pyrene for HepG2 cells, and the negative control was the culture medium itself.

For the test with PBL, whole blood $(0.4 \mathrm{ml})$ was added to $5-\mathrm{ml}$ culture medium (RPMI) that had been supplemented with $10 \%$ FBS plus $10 \mu \mathrm{l} / \mathrm{ml}$ phytohemagglutinin (PHA) to stimulate mitogenesis. The cultures were incubated at $37^{\circ} \mathrm{C}$, under
95\% air and 5\% $\mathrm{CO}_{2}$ in a humidified incubator for 72 hr. After 44-hr incubation, the human leukocytes were treated with five different concentrations of the test extract. After 4-hr treatment, cytochalasin B $(6 \mu \mathrm{g} / \mathrm{ml})$ was added to each culture to block cytokinesis. The cells were harvested by centrifugation ( $5 \mathrm{~min}$ at $850 \mathrm{x} \mathrm{g}$ ), and pellets were resuspended in a chilled hypotonic solution of $0.075 \mathrm{M} \mathrm{KCl}$ for $5 \mathrm{~min}$. The cells were then washed once with $5 \mathrm{ml}$ cold methanol: acetic acid solution $(3: 1, \mathrm{v} / \mathrm{v})$. The fixation procedure was repeated three times. Formaldehyde (1\%) was added after the final repetition to preserve the cytoplasm. The cell suspension was placed on slides and stained with 5\% Giemsa dye diluted in phosphate buffer ( $\mathrm{pH} \mathrm{6.8)} \mathrm{for} 5 \mathrm{~min}$.

In the MN test using HepG2 cells, culture flasks in triplicate were incubated for $24 \mathrm{hr}$ to enable cell growth. Cells were washed again and incubated with five concentrations of extract for $24 \mathrm{hr}$. Cells were then washed and incubated with cytochalasin B for another $28 \mathrm{hr}$. After this point, the procedure was equivalent to the leukocytes. A light microscope (Zeiss, Primo Star) was used to quantify micronucleated cells on the slides, with 1000 binucleate cells scored per culture flask at 100x magnification (Fenech, 2006; OECD 487, 2014). As a measure of cytotoxicity, the nuclear division index (NDI) was calculated according the formula $\mathrm{NDI}=[\mathrm{M} 1+2(\mathrm{M} 2)+3(\mathrm{M} 3)+4(\mathrm{M} 4)] / \mathrm{N}$, where M1-M4 indicate the number of cells with 1-4 nuclei per 500 cells counted $(\mathrm{N})$ (for each culture flask).

\section{Ames test}

C. oxyacantha fruit extract was evaluated in a bacterial mutation assay system, with Salmonella typhimurium tester strains TA98 (frameshift) and TA100 (base-pair substitution), using a pre-incubation methodology both with $(+S 9)$ and without (-S9) metabolism (Maron \& Ames, 1983). The bacteria strains were kindly provided by Dr. B.N. Ames (Berkeley, CA, USA). The strains were grown overnight from frozen cultures for 12-14 hr in Oxoid Nutrient Broth No. 2. The metabolic activation mixture ( $S 9$ fraction), prepared from Sprague-Dawley mice livers treated with the polychlorinated biphenyl mixture Aroclor 1254 (500 
$\mathrm{mg} / \mathrm{kg}$ ), was freshly prepared before each test. The metabolic activation system consisted of $4 \%$ S9 fraction, $1 \% 0.4 \mathrm{M} \mathrm{MgCl} 2,1 \% 1.65 \mathrm{M} \mathrm{KCl}, 0.5 \%$ $1 \mathrm{M}$ D-glucose-6-phosphate disodium and 4\% $0.1 \mathrm{M}$ NADP, $50 \% 0.2 \mathrm{M}$ phosphate buffer, and $39.5 \%$ sterile distilled water. For the mutagenic assessment, six different concentrations of the extract $(2.5,5,10,100,250$, or $500 \mu \mathrm{g} / \mathrm{ml} /$ plate $)$ were tested. The sample concentrations were selected based upon a preliminary toxicity test that determined the highest non-toxic and lowest toxic concentrations. Samples were considered toxic when there was a thinning of the auxotrophic background (i.e., background lawn) accompanied by a decrease in histidine revertants (His+).

The concentrations of the test substances were added to $0.5 \mathrm{ml} 0.2 \mathrm{M}$ phosphate buffer or to 0.5 $\mathrm{ml} 4 \%$ S9 mixture with $0.1 \mathrm{ml}$ bacterial culture and then incubated at $37^{\circ} \mathrm{C}$ for $20-30 \mathrm{~min}$. Two-ml surface agar was added, tubes were mixed, and then, the mixture was poured into a Petri dish containing 20-ml minimal agar. The Petri dishes were incubated at $37^{\circ} \mathrm{C}$ for $66 \mathrm{hr}$ and His+ revertant colonies counted manually. The test was performed in triplicate. Distilled water was used as negative control. The mutagen used as positive control in the tests without S9 mix was 4-nitroquinoline $\mathrm{N}$-oxide (4NQO). For the tests carried out in the presence of $\mathrm{S} 9 \mathrm{mix}$, the positive control was 2-anthramine (2-AA).

\section{Statistical analysis}

The results obtained in the CBMN and comet assays were subjected to analysis of variance (ANOVA) followed by Student's t-test (CBMN) and Tukey's test (comet assay). GraphPad Prism ${ }^{\odot}$ software (version 5.02) was used to perform the statistical analyses. In both tests, the results were considered statistically significant at $\mathrm{p}<0.05$.

For the AMES test, data were analyzed with package SALANAL 1.0 (U.S. Environmental Protection Agency, Monitorin Systems Laboratory, Las Vegas, NV, from Research Triangle Institute, RTP, NC, USA). T Data (revertants/plate) were assessed with ANOVA using the Bernstein et al. (1982) followed by linear regression.

\section{Results}

According to chromatographic analysis, total flavonoid content of C. oxyacantha fruit extract was $2.7 \%$. Four major compounds were identified and quantified: vitexin ( $\mathrm{m} / \mathrm{z} 431.2) 0.1 \%$, isovitexin $(\mathrm{m} / \mathrm{z} 431.2)$ $0.14 \%$, hyperoside ( $\mathrm{m} / \mathrm{z} 463.1) 0.63 \%$, and vitexin-2$O$-rhamnoside ( $\mathrm{m} / \mathrm{z}$ 577.31) $1.79 \%$. Vitexin-2-Orhamnoside was the major compound; transition was monitored by $577.31>292.80 \mathrm{~m} / \mathrm{z}$, which refers to the loss of the sugar moiety, rhamnoside, followed by the loss of C4H8O4, [M - H] - = 577.31; [M - H $\mathrm{C} 6 \mathrm{H} 12 \mathrm{O} 5]-=413.25$ and transition $[\mathrm{M}-\mathrm{H}-$ C6H12O5 - C4H8O4] - = 292.83 (Figure 1(a)-1(c)).

In the PBL assessment, extract concentrations above $100 \mu \mathrm{g} / \mathrm{ml}$ resulted in less than $80 \%$ cell viability, while for HepG2 cells, decreased viability was observed starting at $250 \mu \mathrm{g} / \mathrm{ml}$ concentration (data not shown). Cytotoxicity results for the MTT test were the same as trypan blue exclusion test. These assay results led to the selection of extract concentrations of $2.5,5,10,50$, and $100 \mu \mathrm{g} / \mathrm{ml}$ for assessing genotoxic and clastogenic/aneugenic potential of the extract. The cytotoxicity test performed on TA98 and TA100 Salmonella strains led to the selection of the following concentrations: $2.5,5,10,100,250$, and $500 \mu \mathrm{g} / \mathrm{ml}$.

The results of the comet assay (genotoxicity) are shown in Tables 1 and 2. When the positive control was compared with negative control, a significant difference was noted confirming the test efficacy for detecting DNA damaging agents. Significant increases in total number of cells with DNA damage were found in cells treated with concentrations $\geq 5$ $\mu \mathrm{g} / \mathrm{ml}$. In the cells (nucleoids) where DNA damage was observed, it was predominantly minor (class 1 ). However, in cells treated with extract concentrations of 10 or $50 \mu \mathrm{g} / \mathrm{ml}$, class 2 DNA damage was higher. Data generated in treated PBL were equivalent to those in HepG2 cells (Table 2).

The results of the CBMN test are presented in Tables 3 and 4 . Extract concentrations $\geq 10 \mu \mathrm{g} / \mathrm{ml}$ induced a significant rise in micronucleated binucleate cells compared to negative controls. This effect was detected in both PBL and HepG2 cells, although in HepG2 cells, the frequency of micronucleated cells was higher (Table 4).

Table 5 shows the number of revertant Salmonella typhimurium colonies, and TA98 and 
a)

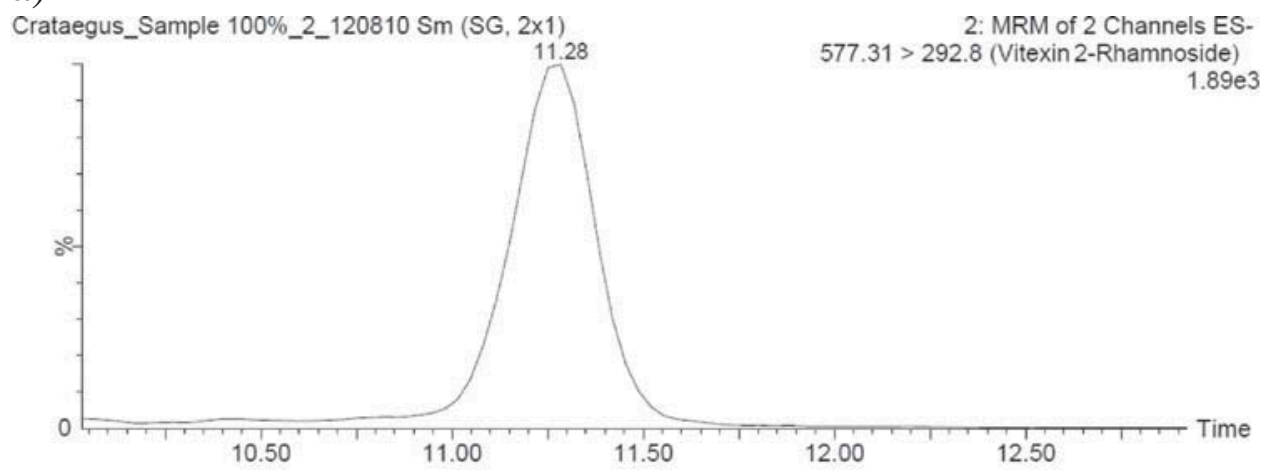

b)

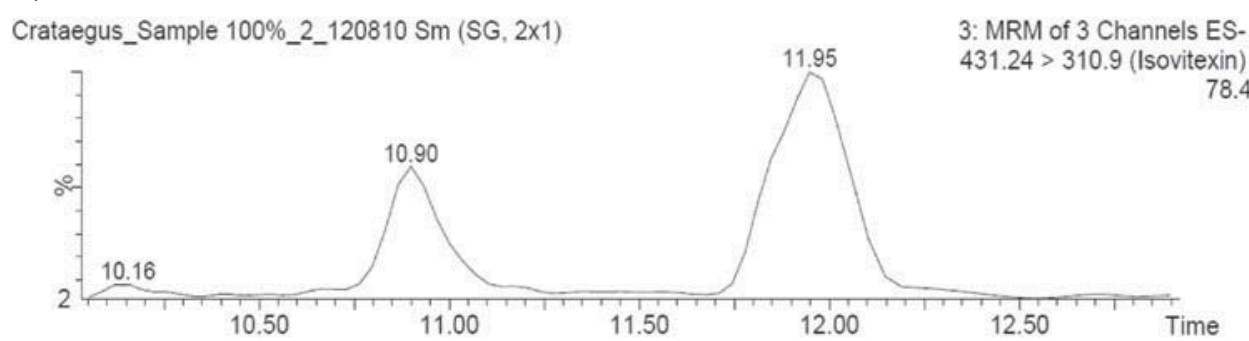

c)

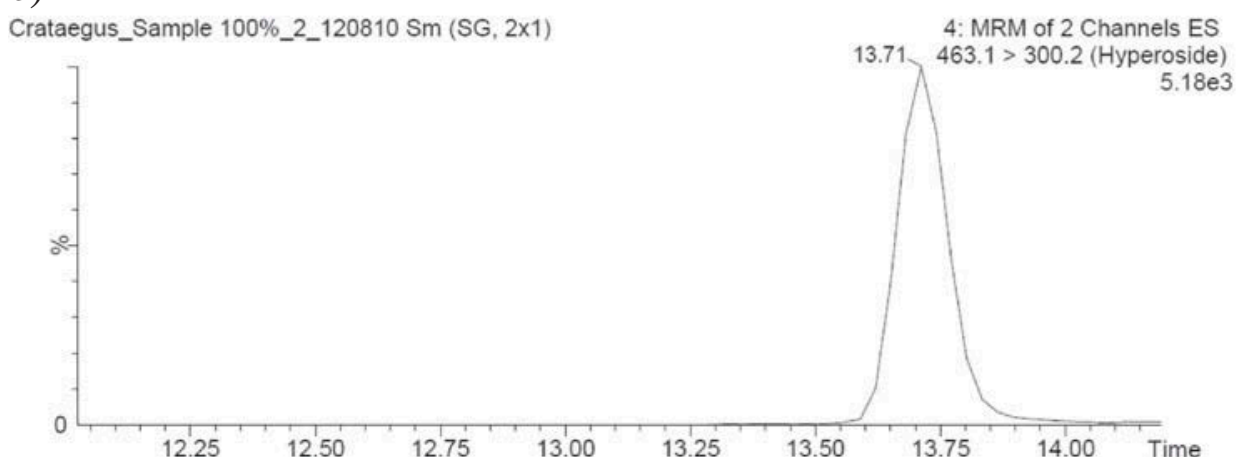

Figure 1. Chromatograms of the Crataegus extract, identifying the compounds: a) vitexin-2-0-rhamnoside extracted at $\mathrm{m} / \mathrm{z} 577.31$ in negative mode ESl; b) vitexin and isovitexin extracted at $\mathrm{m} / \mathrm{z} 431.24$ in negative mode ESl; c) hyperoside extracted at $\mathrm{m} / \mathrm{z} 463.1$ in negative mode ESI.

Table 1. Mean frequency and standard deviation of damaged cells, average distribution between the classes of damage, and average scoring for the assessment of genotoxicity of $C$. oxyacantha fruits extract in mononuclear leukocytes from human blood.

\begin{tabular}{lcccccc}
\hline & & \multicolumn{4}{c}{ Comet class } \\
\cline { 3 - 6 } Treatments & Total $^{1}$ & 0 & 1 & 2 & 3 & Scores \\
\hline Control & $7.50 \pm 1.04$ & $92.50 \pm 1.04$ & $6.83 \pm 0.40$ & $0.83 \pm 0.98$ & $0.00 \pm 0.00$ & $8.33 \pm 2.33$ \\
$2.5 \mu \mathrm{g} / \mathrm{mL}$ & $11.50 \pm 2.51$ & $88.50 \pm 2.51^{*}$ & $10.67 \pm 2.94^{*}$ & $0.83 \pm 0.75$ & $0.00 \pm 0.00$ & $12.33 \pm 2.25$ \\
$5.0 \mu \mathrm{g} / \mathrm{mL}$ & $16.50 \pm 2.07^{*}$ & $83.50 \pm 2.07^{*}$ & $15.17 \pm 1.47^{*}$ & $1.16 \pm 0.75$ & $0.16 \pm 0.40$ & $17.50 \pm 2.58^{*}$ \\
$10 \mu \mathrm{g} / \mathrm{mL}$ & $42.33 \pm 2.87^{*}$ & $57.67 \pm 2.87^{*}$ & $13.83 \pm 1.16^{*}$ & $25.50 \pm 1.64^{*}$ & $3.00 \pm 2.96^{*}$ & $73.83 \pm 7.44^{*}$ \\
$50 \mu \mathrm{g} / \mathrm{mL}$ & $52.17 \pm 2.40^{*}$ & $47.83 \pm 2.40^{*}$ & $22.50 \pm 2.81^{*}$ & $26.50 \pm 1.22^{*}$ & $3.16 \pm 0.98^{*}$ & $85.00 \pm 2.96^{*}$ \\
$100 \mu \mathrm{g} / \mathrm{mL}$ & $64.00 \pm 6.81^{*}$ & $32.67 \pm 2.25^{*}$ & $51.17 \pm 1.72^{*}$ & $14.00 \pm 0.63^{*}$ & $2.16 \pm 0.98$ & $85.67 \pm 3.83^{*}$ \\
$\mathrm{MMS} 75 \mu \mathrm{M}$ & $64.17 \pm 0.75^{*}$ & $35.83 \pm 0.75^{*}$ & $51.50 \pm 0.83^{*}$ & $12.17 \pm 0.75^{*}$ & $0.83 \pm 0.40$ & $77.67 \pm 1.03^{*}$ \\
(Positive control) & & & & & & \\
\hline
\end{tabular}

*Significantly different from the negative control $(p<0.05)$;

${ }^{1}$ Total number of damaged cells (class $1+2+3$ ).

TA100 strains per plate, after treatment with the test extract, in both the presence $(+\mathrm{S} 9)$ and absence (-S9) of metabolic activation. The mutagenicity test showed that all tested concentrations of the extract, after metabolism by S9 fraction, produced mutagenic effects in the TA98 
Table 2. Mean frequency and standard deviation of damaged cells, average distribution between the classes of damage, and average scoring for the assessment of genotoxicity of $C$. oxyacantha fruits extract in HepG2 cells.

\begin{tabular}{lcccccc}
\hline & & \multicolumn{5}{c}{ Comet class } \\
\cline { 3 - 6 } Treatments & Total $^{1}$ & 0 & 1 & 2 & 3 & Scores \\
\hline Control & $10.67 \pm 0.57$ & $89.33 \pm 0.57$ & $10.00 \pm 1.00$ & $0.66 \pm 0.57$ & $0.00 \pm 0.00$ & $11.33 \pm 0.57$ \\
$2.5 \mu \mathrm{g} / \mathrm{mL}$ & $12.67 \pm 0.57$ & $87.33 \pm 0.57$ & $11.33 \pm 0.57$ & $1.33 \pm 0.57$ & $0.00 \pm 0.00$ & $14.00 \pm 1.00$ \\
$5.0 \mu \mathrm{g} / \mathrm{mL}$ & $18.33 \pm 0.57^{*}$ & $81.67 \pm 0.57$ & $17.67 \pm 0.57$ & $0.66 \pm 0.57$ & $0.00 \pm 0.00$ & $19.00 \pm 1.00^{*}$ \\
$10 \mu \mathrm{g} / \mathrm{mL}$ & $39.33 \pm 1.15^{*}$ & $60.67 \pm 1.15^{*}$ & $13.33 \pm 1.52$ & $25.33 \pm 1.52^{*}$ & $0.66 \pm 0.57$ & $66.00 \pm 2.64^{*}$ \\
$50 \mu \mathrm{g} / \mathrm{mL}$ & $54.67 \pm 0.57^{*}$ & $45.33 \pm 0.57^{*}$ & $23.00 \pm 2.00^{*}$ & $28.33 \pm 1.52^{*}$ & $3.33 \pm 0.57^{*}$ & $89.67 \pm 1.52^{*}$ \\
$100 \mu \mathrm{g} / \mathrm{mL}$ & $68.33 \pm 0.57^{*}$ & $31.67 \pm 0.57^{*}$ & $48.33 \pm 1.15^{*}$ & $16.33 \pm 1.15^{*}$ & $3.66 \pm 0.57^{*}$ & $92.00 \pm 1.00^{*}$ \\
$\mathrm{MMS} 75 \mu \mathrm{M}$ & $65.00 \pm 1.00^{*}$ & $35.00 \pm 1.00^{*}$ & $52.33 \pm 0.57^{*}$ & $11.67 \pm 0.57^{*}$ & $1.00 \pm 0.00$ & $78.67 \pm 1.52^{*}$ \\
(Positive control) & & & & & & \\
\hline
\end{tabular}

${ }^{*}$ Significantly different from the negative control $(p<0.05)$.

${ }^{1}$ Total number of damaged cells (class $1+2+3$ ).

Table 3. The micronucleus frequency and Nuclear Division Index (NDI) in human lymphocytes treated with $C$. oxyacantha fruits extract, and respective controls.

\begin{tabular}{|c|c|c|c|c|c|}
\hline \multirow[b]{2}{*}{ Test substance } & \multicolumn{2}{|c|}{ Treatment } & \multicolumn{2}{|c|}{ Binucleated cells With MN (2000 cells scored) } & \multirow{2}{*}{$\frac{\mathrm{NDI} / 1000 \text { cells }}{\text { (Mean } \pm \text { SD) }}$} \\
\hline & Period (h) & Concentration $(\mu \mathrm{g} / \mathrm{mL})$ & $\mathrm{N}^{\circ}$ & $\%$ & \\
\hline Control & 28 & 0 & 6 & 0.30 & $1.75 \pm 0.03$ \\
\hline MMS (Positive control) & 28 & $150^{*}$ & $97^{\mathrm{a}}$ & $4.85^{\mathrm{a}}$ & $1.64 \pm 0.04$ \\
\hline \multirow[t]{5}{*}{ Crataegus oxyacantha } & 28 & 2.5 & 11 & 0.55 & $1.66 \pm 0.01$ \\
\hline & 28 & 5.0 & 10 & 0.50 & $1.72 \pm 0.03$ \\
\hline & 28 & 10 & $14^{\mathrm{a}}$ & $0.70^{\mathrm{a}}$ & $1.75 \pm 0.01$ \\
\hline & 28 & 50 & $16^{\mathrm{a}}$ & $0.80^{\mathrm{a}}$ & $1.75 \pm 0.02$ \\
\hline & 28 & 100 & $16^{\mathrm{a}}$ & $0.80^{\mathrm{a}}$ & $1.74 \pm 0.06$ \\
\hline
\end{tabular}

Note. MN, micronucleus; SD, standard deviation; MMS, Methyl methanesulfonate; ${ }^{*}$ Concentration, $\mu \mathrm{M},{ }^{\mathrm{a}}$ Significantly different from the negative control $(p<0.05)$.

Table 4. The micronucleus frequency and Nuclear Division Index (NDI) in HepG2 cells treated with C. oxyacantha fruits extract, and respective controls.

\begin{tabular}{|c|c|c|c|c|c|}
\hline \multirow[b]{2}{*}{ Test substance } & \multicolumn{2}{|c|}{ Treatment } & \multicolumn{2}{|c|}{ Binucleated cells With MN (3000 cells scored) } & \multirow{2}{*}{$\frac{\mathrm{NDI} / 1500 \text { cell }}{\text { (Mean } \pm \text { SD) }}$} \\
\hline & Period (h) & Concentration $(\mu \mathrm{g} / \mathrm{mL})$ & $\mathrm{N}^{\circ}$ & $\%$ & \\
\hline Control & 24 & 0 & 13 & 0.43 & $1.60 \pm 0.005$ \\
\hline B[a]P (Positive control) & 24 & $150^{*}$ & $146^{\mathrm{a}}$ & $4.86^{\mathrm{a}}$ & $1.62 \pm 0.005$ \\
\hline \multirow[t]{5}{*}{ Crataegus oxyacantha } & 24 & 2.5 & 11 & 0.36 & $1.64 \pm 0.010^{\mathrm{a}}$ \\
\hline & 24 & 5.0 & 14 & 0.46 & $1.62 \pm 0.011^{\mathrm{a}}$ \\
\hline & 24 & 10 & $21^{\mathrm{a}}$ & $0.70^{\mathrm{a}}$ & $1.61 \pm 0.005$ \\
\hline & 24 & 50 & $23^{\mathrm{a}}$ & $0.76^{\mathrm{a}}$ & $1.64 \pm 0.005^{\mathrm{a}}$ \\
\hline & 24 & 100 & $26^{\mathrm{a}}$ & $0.86^{\mathrm{a}}$ & $1.61 \pm 0.005$ \\
\hline
\end{tabular}

Note. MN, micronucleus; SD, standard deviation; B[a]P, Benzo[a]Pyrene; *Concentration, $\mu \mathrm{M},{ }^{\text {a }}$ Significantly different from the negative control ( $\left.\mathrm{p}<0.05\right)$.

Table 5. Mutagenic Assessment of $C$. oxyacantha fruits Extract in Salmonella typhimurium TA98 and TA100 Strains with (+S9) and Without (-S9) Metabolic Activation.

\begin{tabular}{|c|c|c|c|c|}
\hline \multirow[b]{3}{*}{ Treatments $(\mu \mathrm{g} / \mathrm{mL})$} & \multicolumn{4}{|c|}{ Number of revertants (Mean \pm SD)/plate } \\
\hline & \multicolumn{2}{|c|}{ TA 98} & \multicolumn{2}{|c|}{ TA 100} \\
\hline & -59 & +59 & -59 & $+S 9$ \\
\hline $0^{1}$ & $23.00 \pm 3.94$ & $22.00 \pm 2.00$ & $100.20 \pm 9.88$ & $110.50 \pm 17.20$ \\
\hline 2.5 & $28.00 \pm 1.41$ & $1810.67 \pm 327.96^{\mathrm{a}}$ & $102.33 \pm 3.06$ & $104.67 \pm 12.01$ \\
\hline \multirow[t]{2}{*}{5.0} & $26.67 \pm 6.43$ & $3238.00 \pm 557.20^{\mathrm{a}}$ & $108.67 \pm 17.67$ & $107.00 \pm 3.00$ \\
\hline & $28.33 \pm 2.08$ & $584.50 \pm 188.80^{\mathrm{a}}$ & $98.33 \pm 13.01$ & $105.67 \pm 10.50$ \\
\hline 100.0 & $24.33 \pm 5.03$ & $1801.00 \pm 74.95^{\mathrm{a}}$ & $119.00 \pm 4.36$ & $99.00 \pm 11.79$ \\
\hline 250.0 & $27.00 \pm 2.65$ & $3574.00 \pm 183.85^{\mathrm{a}}$ & $104.00 \pm 4.00$ & $107.67 \pm 8.33$ \\
\hline 500.0 & $25.00 \pm 5.20$ & $3402.67 \pm 165.71^{\mathrm{a}}$ & $116.00 \pm 11.27$ & $107.00 \pm 3.61$ \\
\hline
\end{tabular}

Note. Data are expressed as mean and standard deviation of the number of revertants.

${ }^{1}$ Negative control: dimethyl sulfoxide (DMSO, $100 \mu \mathrm{L} /$ plate); ${ }^{a}$ Significantly different from the negative control by ANOVA ( $\left.p<0.05\right)$. 
strain. In contrast, the extract without S9 fraction induced no marked mutagenic effects in both strains.

\section{Discussion}

Cell viability and cytotoxicity tests carried out with C. oxyacantha fruit extract demonstrated that concentrations above $100 \mu \mathrm{g} / \mathrm{ml}$ resulted in decreased cell viability and/or population of human cells in culture. Further, concentrations above $500 \mu \mathrm{g} / \mathrm{ml}$ were cytotoxic to TA98 and TA100 strains of Salmonella. The cytotoxicity of the fruit extract observed in our in vitro study was higher than that reported for animals with the extract of aerial parts. The German Commission E monography states that mice and rats have been safely given a standardized extract at doses up to $3 \mathrm{~g} / \mathrm{kg}$ body weight (Blumenthal et al., 1998). In humans, the acute oral toxicity of hawthorn was $6 \mathrm{~g} / \mathrm{kg}$.

The results of the present study showed that extract concentrations of $5 \mu \mathrm{g} / \mathrm{ml}$ or higher produced genotoxic effects in two types of mammalian cells. The CBMN results indicate that $C$. oxyacantha fruit extract mediated clastogenic and/or aneugenic effects in both tested types of cultured human cells at concentrations of $10 \mu \mathrm{g} / \mathrm{ml}$ or higher. Our study also demonstrated that the TA98 strain, after extract metabolism by S9 fraction, induced a significant increase in number of revertant colonies, indicating that the chemical components of the extract, after undergoing metabolism, might form mutagenic products capable of inducing insertion and/or deletion of DNA base pairs (frameshift mutations).

Tabach et al. (2009) developed a preclinical toxicological evaluation of a phytotherapeutic product termed CPV, which consists of C. oxyacantha aerial part extract $(26.7 \%)$ in association with Passiflora incarnata (33.3\%) and Valeriana officinalis (40 \%) extracts. Several parameters were investigated in their study including, teratogenicity, mutagenicity, and genotoxicity. Tabach et al. (2009) reported that all of the results were negative, indicating that CPV presented no apparent marked toxicity and appeared devoid of risk for humans. It is possible that the differences between positive genotoxicity results noted in our in vitro study compared to Tabach et al. (2009) may be attributed to the fact that a mixture of three plant extracts was used in which the proportion of $C$. oxyacantha aerial part extract (leaves, flowers, and fruits) was smaller and of a different chemical composition than the C. oxyacantha fruit extract tested in our study.

The chemical characterization of C. oxyacantha fruit extract illustrated significant flavonoid content, including vitexin, isovitexin, hyperoside, and vitexin-2-O-rhamnoside as major compounds. Choo et al. (2012) conducted an in vivo acute toxicity test of vitexin and isovitexin by administering them to diabetic and normoglycemic rats and found no apparent signs of toxicity or significant body weight change during the study period. Wenjuan-Wei et al. (2014) examined the effects of vitexin-2$O$-rhamnosideo and vitexin-4-O-glucoside on cell growth and apoptosis noting that these compounds exerted no marked cytotoxic effects on human cells derived from adipose tissue. However, few available studies exist, evaluating genetic toxicity of the major components or similar in C. oxyacantha fruit extract. Several investigators demonstrated the cytotoxic/mutagenic potential assessment of some flavonoids present in C. oxyacantha or other plant genus. Jhoo et al. (2007) identified C-glycoside flavonoids 2-Orhamnosylvitexin and schaftoside as potential mutagenic compounds in Kava (Piper methysticum) by the umu test, a sensitive test for point mutations. Snijman et al. (2007) evaluating the antimutagenic activity of the major flavonoids of rooibos (Aspalathus linearis), by using the Ames test, observed that flavonoid-mutagen interactions ranged from antimutagenic, comutagenic, and promutagenic to mutagenic, while vitexin, isovitexin, and hyperoside exhibited only antimutagenic effects. Mohammed et al. (2014) reported potent cytotoxic activity of flavonoids constituents from Gleditsia tricanthos L. leaves, against liver, breast, cervix, larynx, and colon cancer cell lines, with vitexin displaying intermediate actions.

In general, toxicity assessments of different formulations of Crataegus extract in animals and humans demonstrated low toxicity and few side effects (Ammon \& Händel, 1981). Nascimento (2009) tested the potential toxicity of a mix of 
extracts from Passiflora incarnata, Crataegus oxyacantha, and Salix alba on humans with clinical, cardiology, and laboratory exams and found that the administration of this phytotherapeutic compound twice a day for $28 \mathrm{~d}$ produced no apparent toxicity. Transient side effects including dizziness, gastrointestinal complaints, headaches, and heart palpitations were reported only occasionally (Daniele et al., 2006).

Under the experimental conditions employed in the present study, the fruit extract of $C$. oxyacantha produced genotoxic and clastogenic/aneugenic effects in human PBL and HepG2 cells, as well as induced frameshift mutation in the TA98 strain of $S$. typhimurium after metabolism by $\mathrm{S} 9$ liver enzymes. Despite the therapeutic potential of C. oxyacantha fruit extract for humans, these effects raise concern and suggest the need for further in vitro and in vivo studies investigating genetic toxicity.

\section{Funding}

This study was supported by FAPESP (Fundação de Amparo à Pesquisa do Estado de São Paulo, Brazil) (Grant: 2014/ 26882-2).

\section{References}

Alp, H., Soner, B. C., Baysal, T., and Şahin, A. S. 2015. Protective effects of Hawthorn (Crataegus oxyacantha) extract against digoxin-induced arrhythmias in rats. Anat. J. Cardiol. 15: 970-975.

Ammon, H. P. and Händel, M. 1981. Crataegus, toxicology and pharmacology, Part I: Toxicity (author's transl). Planta Med. 43: 105-120.

Azqueta, A., Meier, S., Priestley, C., Gutzkow, K. B., Brunborg, G., Sallete, J., Soussaline, F., and Collins, A. 2011. The influence of scoring method on variability in results obtained with the comet assay. Mutagenesis 26: 393-399.

Bahorun, T., Aumjaud, E., Ramphul, H., Rycha, M., Luximon-Ramma, A., Trotin, F., and Aruoma, O. I. 2003. Phenolic constituents and antioxidant capacities of Crataegus monogyna (Hawthorn) callus extracts. Nahrung 47: 191-198.

Belščakcvitanović, A., Durgo, K., Bušić, A., Franekić, J., and Komes, D. 2014. Phytochemical attributes of four conventionally extracted medicinal plants and cytotoxic evaluation of their extracts on human laryngeal carcinoma (HEp2) cells. J. Med. Food 17: 206-217.
Bernstein, L., Kaldor, J., McCann, J., and Pike, M. C. 1982. An empirical approach to the statistical analysis of mutagenesis data from the Salmonella test. Mutat. Res. 97: 267-281.

Blumenthal, M., Busse, W., and Goldberg, A. 1988. The complete German Commission E monographys, 142-144. Boston, MA: American Botanical Council.

Chang, W. T., Dao, J., and Shao, Z. H. 2005. Hawthorn: Potential roles in cardiovascular disease. Am. J. Chin. Med. 33: 1-10.

Choo, C. Y., Sulong, N. Y., Man, F., and Wong, T. W. 2012. Vitexin and isovitexin from the leaves of Ficus deltoidea with in vivo a-glucosidade inhibition. J. Ethnopharmacol. 142: 776-781.

Choy, W. N. 2001. Genetic toxicology and cancer risk assesment. New York: Marcel Dekker, Inc.

Claxton, L. D., Umbuzeiro, G. A., and DeMarini, D. 2010. The Salmonella mutagenicity assay: The stethoscope of genetic toxicology for the 21st Century. Environ. Health Persp. 118: 1515-1522.

Daniele, C., Mazzanti, G., Pittler, M. H., and Ernst, E. 2006. Adverse-event profile of Crataegus spp.: A systematic review. Drug Saf. 29: 523-535.

Fairbairn, D. W., Olive, P. L., and O’Neill, K. L. 1995. The comet assay: A comprehensive review. Mutat. Res. 339: 37-59.

Fenech, M. 2000. The in vitro micronucleus technique. Mutat. Res. 455: 81-95.

Fenech, M. 2006. Cytokinesis-block micronucleus assay evolves into a "cytome" assay of chromosomal instability, mitotic dysfunction and cell death. Mutat. Res. 600: 58-66.

Franco, E. S., Melo, E. S., Militão, G. C. G., Rocha, R. E. T., Silva, L. T. G. A., Jatobá, B. J. A., Silva, P. B. N., Santana, A. L. B. D., Silva, A. A. R., Silva, T. G., Nascimento, M. S., Maia, M. B. S. 2015. Evaluation of the acute toxicity, cytotoxicity, and genotoxicity of Chresta martii (Asteraceae). J. Toxicol. Environ. Health A 78: 1083-1093.

Hartmann, A. and Speit, G. 1997. The contribution of cytotoxicity to DNA-effects in the single cell gel test (comet assay). Toxicol. Lett. 90: 183-188.

Hosseinimehr, S. J., Mahmoudzadeh, A., Azadbakht, M., and Akhlaghpoor, S. 2009. Radioprotective effects of Hawthorn against genotoxicity induced by gamma irradiation in human blood lymphocytes. Radiat. Environ. Biophys. 48: 95-98.

Hosseinimehr, S. J., Azadbakht, M., Mousavi, S. M., Mahmoudzadeh, A., and Akhlaghpoor, S. 2007. Radioprotective effects of hawthorn fruit extract against gamma irradiation in mouse bone marrow cells. J. Radiat. Res. 48: 63-68.

Hosseinimehr, S. J., Azadbakht, M., Tanha, M., Mahmodzadeh, A., and Mohammadifar, S. 2011. Protective effect of hawthorn extract against genotoxicity induced by methyl methanesulfonate in human lymphocytes. Toxicol. Ind. Health 27: 363-369.

Jayalakshmi, R. and Niranjali-Devaraj, S. 2004. Cardioprotective effect of tincture of Crataegus on isoproterenol-induced myocardial infarction in rats. J. Pharm. Pharmacol. 56: 921-926. 
Jhoo, J. W., Ang, C. Y., Heinze, T. M., Deck, J., Schnackenberg, L. K., Beger, R. D., Gragull, K., and Tang, C. S. 2007. Identification of C-glycoside flavonoids as potential mutagenic compounds in Kava. J. Food Sci. 72: C120-C125.

Maron, D. M. and Ames, B. N. 1983. Revised methods for the Salmonella mutagenicity test. Mutat. Res. 113: 173-215.

Mohammed, R. S., Abou-Zeid, A. H., El-Hawary, S., Sleem, A. A., Ashour, W. E. 2014. Flavonoid constituents, cytotoxic and antioxidant activities of Gleditsia triacanthos L. leaves. Saudi J. Biol. Sci. 21: 547-553.

Mosmann, T. 1983. Rapid colorimetric assay for cellular growth and survival: Application to proliferation and cytotoxicity assays. J. Immunol. Meth. 65: 55-63.

Nascimento, D. F. 2009. Estudo de toxicologia clínica de um fitoterápico contendo Passiflora incarnata L., Crataegus oxyacantha L. e Salix alba L. em voluntários saudáveis. Braz. J. Pharmacog. 261.

OECD, 487. 2014. In vitro mammalian cell micronucleus test. OECD guideline for the testing of chemicals. Paris, France.

OECD, 489. 2014. In vivo mammalian alkaline comet assay. OECD Guideline for the testing of Chemicals. Paris, France.

Rigelsky, J. M. and Sweet, B. V. 2002. Hawthorn: pharmacology and therapeutic uses. Am. J. Health Syst. Pharm. 59: 417-422.

Riss, T. L. 2013. Cell viability assays. Bethesda: Assay guidance manual.

Strober, W. 2001. Trypan blue exclusion test on cell viability. Curr. Protoc. Immunol. doi:10.1002/0471142735. ima03bs21.

Snijman, P. W., Swanevelder, S., Joubert, E., Green, I. R., Gelderblom, W. C. A. 2007. The antimutagenic activity of the major flavonoids of rooibos (Aspalathus linearis):
Some dose-response effects on mutagen activation-flavonoid interactions. Mutat. Res. 631: 111-123.

Tabach, R., Rodrigues, E., and Carlini, E. A. 2009. Preclinical toxicological assessment of a phytotherapeutic productCPV (based on dry extracts of Crataegus oxyacantha L., Passiflora incarnata L., and Valeriana officinalis L.). Phytother. Res. 23: 33-40.

Tice, R. R., Agurell, E., Anderson, D., Burlinson, B., Hartmann, A., Kobayashi, H., Miyamae, Y., Rojas, E., Ryu, J. C., and Sasaki, Y. F. 2000. Single cell gel/comet assay: Guidelines for in vitro and in vivo genetic toxicology testing. Environ. Mol. Mutagen. 35: 206-221.

Trindade, C., Bortolini, G. V., Costa, B. S., Anghinoni, J. C., Guecheva, T. N., Arias, X., Césio, M. V., Heinzen, H., Moura, D. J., Saffi, J., Salvador, M., and Henriques, J. A. P. 2016. Antimutagenic and antioxidant properties of the aqueous extracts of organic and conventional grapevine Vitis labrusca cv. Isabella leaves in V79 cells. J. Toxicol. Environ. Health A 79: 825-836.

Wang, J., Xiong, X., and Feng, B. 2013. Effect of Crataegus usage in cardiovascular disease prevention: an evidencebased approach. Evid. Based Complement. Alternat. Med. 2013: 149363.

Weihmayr, T. and Ernst, E. 1996. Therapeutic effectiveness of Crataegus. Fortschr. Med. 114: 27-29.

Wenjuan-Wei, W., Ying, X., Zhang, W., Chen, Y., Leng, A., and Jiang, C. 2014. Effects of vitexin-2"-O-rhamnoside and vitexin-4"-O-glucoside on growth and oxidative stressinduced cell apoptosis of human adipose-derived stem cells. J. Pharm. Pharmacol. 66: 988-997.

Zhang, Z., Chang, Q., Zhu, M., Huang, Y., Ho, W. K., and Chen, Z. 2001. Characterization of antioxidants present in hawthorn fruits. J. Nutr. Biochem. 12: 144-152. 